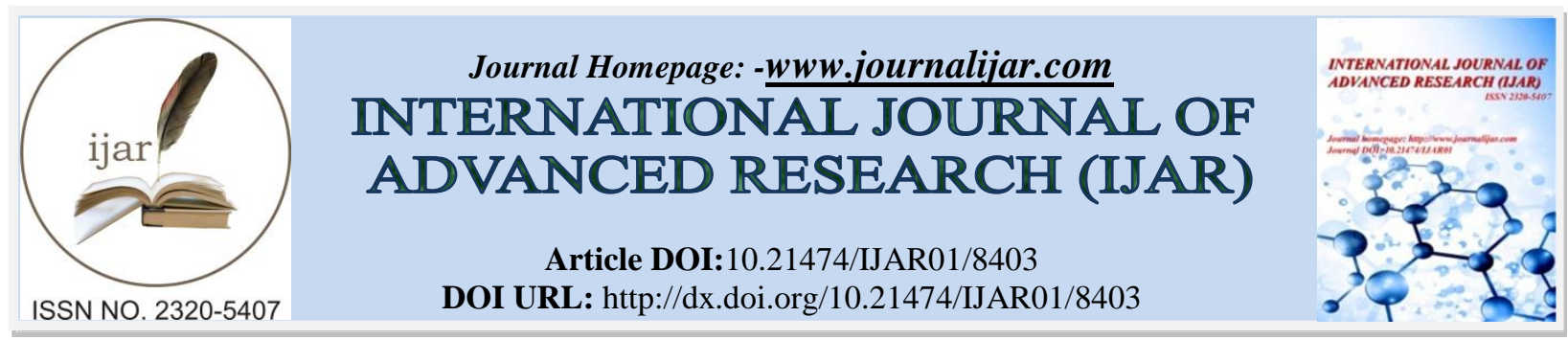

RESEARCH ARTICLE

\title{
OCCUPATIONAL ASPIRATION OF UNDERGRADUATES IN MEGHALAYA.
}

\author{
Nikme S. C Momin ${ }^{1}$ and Geetam Chetry ${ }^{2}$. \\ 1. Professor \& Head, Department of Education, NEHU, Tura Campus. \\ 2. Research Scholar, Department of Education, NEHU, Tura Campus.
}

\section{Manuscript Info}

Manuscript History

Received: 14 November 2018

Final Accepted: 16 December 2018

Published: January 2019

Key words:-

OccupationalAspiration,Undergraduates.

\begin{abstract}
College graduates are the backbone of the knowledge economy and, therefore, it is imperative to understand the Occupational Aspiration of the undergraduates. The objective of the research work was to compare the mean scores of Occupational Aspiration of Male and Female Undergraduates. The sample comprised of 160 students from Arts Stream of two degree colleges of Tura, Meghalaya. Occupational Aspiration Scale by Chandel, Laxmi and Singh was selected to measure Occupational Aspiration. Data analysis was done with the help of $t$-test. The finding revealed a significant difference in the Mean scores of Occupational Aspiration of Male and Female Undergraduates, with Males having significantly higher Occupational Aspiration than the Females.
\end{abstract}

Copy Right, IJAR, 2018,. All rights reserved.

\section{Introduction:-}

College graduates are the backbone of our knowledge economy in that, in India, as per the All India Survey on Higher Education (AISHE, 2016-17), student enrolment is the highest (79.4\%) at the undergraduate level. Of the diverse streams at the undergraduate level, as per the same survey, there is highest enrolment of students in the Arts Stream $(34.48 \%)$ with $47.1 \%$ males and $52.9 \%$ females. Hence, there is highest number of student turn-out in Arts stream (33\%) with $42.9 \%$ males and $57.1 \%$ females. These students, after graduation, enter the knowledge economy to translate their aspirations into reality and compete for prestigious jobs. However, as noted in EmploymentUnemployment Survey (EUS, 2015-16), in India, the unemployment rate (58\% for graduates) was found to go up with the level of education, the main reason being non-availability of jobs matching education/skills and experience. Further, contrary to the high enrolment and turn-out rate of female undergraduates, their Labour Force Participation Rate (LFPR) is observed to be lower among educated women (ILO, 2017).

Since higher levels of education are important predictors of a nation's economic success (Mau as cited in Wahl and Blackhurst, 2000), the unemployment of the graduates and the low LFPR of females are serious issues which need to be addressed for future success and growth of India's knowledge economy. It, therefore, becomes necessary to understand all underlying factors, one such being the Occupational Aspiration of the undergraduates.

Occupational Aspirations are useful predictors of later educational and occupational choices (Mau and Bikos as cited in Patton and Creed, 2007). They refer to the assimilation of an individual's assessment of the compatibility and accessibility of an occupation (Gottfredson as cited in Marshall, 2010). They are an individual's expressed

Corresponding Author:-Nikme S. C Momin.

Address:-Professor \& Head, Department of Education, NEHU, Tura Campus. 
career related goals or choices that provide important motivational momentum for career-related behaviours and future educational and career success (Rojewski as cited in Creed, Yin and Hood, 2009).

\section{Review of Related Literature:-}

A perusal of related literature showed that most studies on Occupational Aspiration were done on adolescents in secondary and higher secondary schools. Very few research works examined the Occupational Aspiration of the undergraduates in degree colleges. Available studies conducted on the undergraduates revealed inconsistent findings with regards to Gender. Lyngdoh (1975) found that the undergraduate girls' aspirations for occupation were higher than that of the boys. Kumar (2014) and Gjerustad (2016) found no gender differences in occupational aspiration. Passah (2014) and Mistry (2015) found the male undergraduates to have higher level of occupational aspirations as compared to females. Hence, the present research work aims to fill this research gap and add to the repertoire of findings so as to help in reaching a definite conclusion pertaining to the influence Gender has on Occupational Aspiration.

\section{Objective:-}

The sole objective of the research work was to compare the Mean scores of Occupational Aspiration of Male and Female Undergraduates.

\section{Hypothesis:-}

It was hypothesised that there is no significant difference in the Mean scores of Occupational Aspiration of Male and Female Undergraduates.

\section{Sample of the Study:-}

The sample comprised of 74 Males and 86 Females, with a total of 160 Undergraduates, selected purposively from two degree colleges of Tura, Meghalaya. The selected sample was delimited to Final Year Students from Arts Stream of 2014-15 Annual Batch.

\section{Research Tool:-}

Occupational Aspiration Scale (OAS_CnLvsR, 2012) by Prof. N.P.S. Chandel, Dr. VibhaLaxmi and Ranjeet Kumar Singh was selected to measure the variable of the study. The consumable booklet of the tool includes a set of instructions and 8 question items with 10 options each which are a list of occupation titles arranged in a mixed order.

\section{Statistical Technique:-}

After ensuring that the collected data does not violate the assumptions of Independence of Observations, Normality $($ Shapiro-Wilk Statistic $=.98 ; d f=160 ; p=.07)$ and Homogeneity of Variance $\left(F_{\text {Levene }}=.27 ; d f=1 / 158 ; p=.60\right)$, analysis was done with the help of $t$-test.

\section{Result of the Study:-}

The objective was to compare the Mean scores of Occupational Aspiration of Male and Female Undergraduates. The data was analysed with the help of SPSS (Version 20) and the result is presented in Table 1.

Table 1:-Gender-wise N, Mean, SD and t-Value of Occupational Aspiration of the Undergraduates

\begin{tabular}{|c|c|c|c|c|}
\hline Gender & N & Mean & SD & $t$ \\
\hline Male & 74 & 55.12 & 10.21 & $4.67 * *$ \\
\hline Female & 86 & 47.91 & 9.33 & \\
\hline
\end{tabular}

** Significant at .01 level

It is evident from Table 1 that the $t$-value which is 4.67 , is significant at .01 level with $d f=158$. It indicates that the Mean scores of Occupational Aspiration of Male and Female Undergraduates differ significantly. Thus, the Null Hypothesis which states that there is no significant difference in the Mean scores of Occupational Aspiration of Male and Female Undergraduates is rejected. Further, the Mean score of Occupational Aspiration of Male Undergraduates $(M=55.12)$ was found to be significantly higher than that of Female Undergraduates $(M=47.91)$. It may, therefore, be said that the Male Undergraduates were found to have significantly higher Occupational Aspiration than the Female Undergraduates. 
In order to know the Level of Occupational Aspiration of the undergraduates, Percentile Norms provided in the Test Manual for Final Year Undergraduates was utilised. The Level of Occupational Aspiration was clubbed into three broad Levels - High, Average and Low. The percentage of Males, Females and Overall Undergraduates having High, Average and Low Levels of Occupational Aspiration was computed and is presented in Table 2.

Table 2:-Level and Percentage of Occupational Aspiration (OA) of Undergraduates

\begin{tabular}{|c|c|c|c|c|}
\hline \multirow{2}{*}{ Percentile Range } & \multirow{2}{*}{ Level of OA } & \multicolumn{3}{|c|}{ Percentage of Undergrauates } \\
\cline { 3 - 5 } & & 34 & 8 & Overall \\
\hline $\mathrm{P}_{76}$ Above & High & 50 & 51 & 51 \\
\hline $\mathrm{P}_{26}$ to $\mathrm{P}_{75}$ & Average & 16 & 41 & 29 \\
\hline $\mathrm{P}_{25}$ Below & Low & Female & \\
\hline
\end{tabular}

From Table 2, it can be seen that maximum Males (50\%), Females (51\%) and Overall Undergraduates (51\%) had Average Level of Occupational Aspiration. However, more Males (34\%) than Females (8\%) had High Level of Occupational Aspiration, while more Females (41\%) than Males (16\%) had Low Level of Occupational Aspiration.

\section{Discussion:-}

The finding of the study is in conformity to the findings by Passah (2014) and Mistry (2015) who reported the undergraduate males to have higher Occupational Aspiration than the females. A possible explanation for this could be as noted by Lee and Rojewski (2009) that after high school, females were more likely to lower their Occupational Aspiration than males. Several factors may account for the low Occupational Aspiration of Females. These factors could be personal, such as lack of motivation, interest, aptitude, skills, awareness and encouragement; or it could be societal, such as lack of available career opportunities, barriers to attain the occupation of choice, restrictions pertaining to social mobility, increasing pressure of social expectations, and instinctively conforming to stereotypical social roles of child-bearing and home-making.

Though the males were found to have higher Occupational Aspiration than the females in terms of Mean Scores, however, in terms of Percentile scores, maximum Undergraduates, both Males and Females, were found to have Average Level of Occupational Aspiration. Considering the fact that these undergraduates are in the threshold of assuming adult roles, they may feel increasing pressure to determine immediate and long-term future goals related to education, work and family life (Lee and Rojewski, 2009). This may further be compounded by other factors like lack of career awareness and employability skills, increasing competition for prestigious government jobs, and lack of alternative career opportunities. This could possibly explain why the Undergraduates have Average level of Occupational Aspiration.

\section{Suggestions:-}

The major limitation of the study is that it was conducted only on a sample of undergraduates in Arts Stream. Therefore, the finding cannot be generalised to all undergraduates in various streams. Hence, further research needs to be done on Occupational Aspiration of undergraduates in different streams of study to be able to make significant inferences. Further research also needs to be done on the underlying factors accounting for low Occupational Aspiration of female undergraduates in Meghalaya on the ground that the LFPR of women in Meghalaya (46.7\%) exceeds the national average of $23.7 \%$ (EUS, 2015-16). The career guidance needs of the undergraduates must also be addressed through various initiatives such as career counselling, career talks and integration of skill oriented courses in the curriculum. A database of the student's skills, career interests, preferences, and aspirations should be maintained by the colleges in order to understand their career related behaviour and to help them make better career decisions. And lastly, since unemployment can lead to lowered future aspirations and can have aggravating consequences for the well-being of both the individual and the society (Borrero, 1980; Galadima, 2014; Jakimovski, 2010; Saunders, 2002), more job opportunities must be created by the government in the knowledge sector to cater to the varied aspirations of the students and to ensure maximum employment of the graduates.

\section{Reference:-}

1. All India Survey on Higher Education (AISHE, 2016-17). Government of India. Ministry of Human Resource Development. Department of Higher Education, New Delhi. Retrieved from http://aishe.nic.in

2. Borrero, M. (1980). Psychological and emotional impact of unemployment. The Journal of Sociology \& Social Welfare: Vol. 7(6), Article 12. Available from https://scholarworks.wmich.edu 
3. Creed, P. A., Yin, W.O, \& Hood, M. (2009). Career decision-making, career barriers and occupational aspirations in Chinese adolescents. International Journal for Educational and Vocational Guidance. Available from http://citeseerx.ist.psu.edu

4. Fifth Employment-Unemployment Survey (EUS, 2015-16). Volume I. Government of India. Ministry of Labour\& Employment. Labour Bureau, Chandigarh. Retrieved from

http://labourbureaunew.gov.in

5. Galadima, M. (2014). Effects of youth unemployment and its consequence: A survey of youth in Yobe State, Nigeria. IOSR Journal of Humanities and Social Science.Vol.19 ( 9), pp. 91-95. Retrieved from www.iosrjournals.org

6. Gjerustad, C. (2016). Occupational aspirations- development and consequences of failure in achievement (Doctoral Dissertation, University of Oslo). Retrieved from https://www.duo.uio.no

7. International LabourOrganisation (ILO, 2017). India Labour Market Update. ILO Country Office for India. Retrieved from https://www.ilo.org

8. Jakimovski, J. (2010). Unemployment as a complex and serious personal and social issue. ŠkolaBiznisa, Broj 1. UDC 331.56. Retrieved from http://www.vps.ns.ac.rs/SB/2010/1.7.pdf

9. Mistry, R. (2015). Career aspirations and academic Achievement among the college Students a social work Perspective (Doctoral Thesis, M.S. University of Baroda). Retrieved from Shodhganga@INFLIBNET Database

10. Kumar, M. (2014). A study of interaction effect of some personality correlates and socio economic status on vocational aspiration and occupational choices of professional college students. (Doctoral Thesis,ChaudharyCharan Singh University). Retrieved from Shodhganga@INFLIBNET Database

11. Lee, I. \&Rojewski, J. (2009). Development of occupational aspiration prestige: a piecewise latent growth model of selected influences. Journal of Vocational Behavior, Vol.75(1). Available from https://doi.org

12. Lyngdoh, K.S. (1975). A study of the achievement motive, fear of failure,Concerns, occupational aspirations and family:Influence of the college tribal and non-tribalboys and girls of Meghalaya (Shillong). (Doctoral Thesis, M.S University of Baroda). Retrieved from Shodhganga@INFLIBNET Database

13. Marshall, J. (2010). A longitudinal study of the occupational aspirations and perceptions of fifteen to sixteen year-old South African adolescents (Master's Thesis in Counselling Psychology, Nelson Mandela Metropolitan University). Retrieved from http://dspace.nmmu.ac.za

14. Passah, P. (2014). A study of occupational aspiration among the under graduate students of Shillong. (Doctoral Thesis, North-Eastern Hill University). Retrieved from Shodhganga@ INFLIBNET Database

15. Patton, W. \& Creed, P.A. (2007). Occupational aspirations and expectations of Australian adolescents. Australian Journal of Career Development, 16(1), pp. 46-59. Available from http://eprints.qut.edu.au

16. Saunders, P. (2002). The direct and indirect effects of unemployment on poverty and inequality. Discussion Paper No. 118. The Social Policy Research Centre. University of New South Wales,Australia. Retrieved from www.sprc.unsw.edu.au

17. Wahl, K.H. \&Blackhurst, A. (2000). Factors affecting the occupational and educational aspirations of children and adolescents. Professional School Counselling. Vol. 3 (5). Retrieved from JSTOR Database. 